\title{
Analysis Documentation
}

National Cancer Institute

\section{Source}

National Cancer Institute. Analysis Documentation. NCI Thesaurus. Code C115632.

Records of the analysis of data generated during a clinical trial. 